\title{
VARIASI SUHU PEMADATAN CAMPURAN AC-WC MENGGUNAKAN BATU SUNGAI BALUSU KABUPATEN TORAJA UTARA
}

\author{
Andri Rombe Seppo ${ }^{1}$, Rais Rachman ${ }^{2}$, Nur $\mathrm{Ali}^{3}$ \\ 1),2),3) Program Studi Teknik Sipil, Universitas Kristen Indonesia Paulus \\ Jl. Perintis Kemerdekaan KM 13 Daya, Makassar \\ Email : andryrombe98@gmail.com, rais.rachman@ukipaulus.ac.id, nuralimti@gmail.com
}

\begin{abstract}
One of the factors that determines the conservation of road construction is the temperature of compaction at the time of carrying out the work, this will affect the viscosity of the asphalt used. To obtain information about the temperature range, it is necessary to check the sensitivity of the bitumen to temperature. The research objective was to determine the effect of compaction temperature by using several temperature variations in the $A C$-WC mixture. The aggregate used comes from the Balusu river, North Toraja Regency. Mixing temperature variations were $90{ }^{\circ} \mathrm{C}, 100{ }^{\circ} \mathrm{C}, 110{ }^{\circ} \mathrm{C}$, $120^{\circ} \mathrm{C}, 130^{\circ} \mathrm{C}$ while the asphalt content was 6\%. This research was based on the Specifications of Bina Marga 2018 Division 6. The result was that stones from the Balusu River were applicable as an aggregate in the Asphalt Concrete-Wearing Course (AC-WC) mixture. The compaction temperature variations of $90{ }^{\circ} \mathrm{C}, 100{ }^{\circ} \mathrm{C}, 110{ }^{\circ} \mathrm{C}, 120{ }^{\circ} \mathrm{C}$ and $130{ }^{\circ} \mathrm{C}$ to the characteristics of the mixture in the conventional Marshall test met the requirements of Bina Marga specifications. Marshall stability of the remainder of the mixture with a compaction temperature of $130^{\circ} \mathrm{C}$ and Immersion for 24 hours with asphalt was $6 \%$, then, the AC-WC mixture was resistant to the effects of water, temperature and weather.
\end{abstract}

Keywords: Characteristics, Compaction, Marshall Immersion, Temperature.

\begin{abstract}
Abstrak
Salah satu faktor yang menentukan kekekalan konstruksi jalan adalah suhu pemadatan pada saat pelaksanaan pekerjaan hal ini akan mempengaruhi viskositas aspal yang digunakan. Untuk memperoleh infomasi tentang rentang temperatur perlu dilakukan pemeriksaan sifat kepekaan aspal terhadap temperatur. Tujuan penelitian untuk mengetahui pengaruh suhu pemadatan dengan menggunakan beberapa variasi suhu dalam campuran AC - WC. Agregat yang digunakan berasal dari sungai Balusu Kabupaten Toraja Utara. Variasi suhu pencampuran adalah $90^{\circ} \mathrm{C}, 100^{\circ} \mathrm{C}, 110^{\circ} \mathrm{C}, 120^{\circ} \mathrm{C}, 130^{\circ} \mathrm{C}$ sedangkan kadar aspal adalah 6\%. Penelitian ini didasarkan pada Spesifikasi Bina Marga 2018 Divisi 6. Hasil penelitian menunjukkan batu dari Sungai Balusu dapat digunakan sebagai agregat pada campuran Asphalt Concrete-Wearing Course (AC-WC). Variasi suhu pemadatan $90^{\circ} \mathrm{C}, 100^{\circ} \mathrm{C}, 110^{\circ} \mathrm{C}, 120^{\circ} \mathrm{C}$ dan $130^{\circ} \mathrm{C}$ terhadap karakteristik campuran pada pengujian Marshall konvensional memenuhi persyaratan spesifikasi Bina Marga. Stabilitas Marshall Sisa campuran dengan suhu pemadatan $130^{\circ} \mathrm{C}$ dan perendaman dengan durasi perendaman 24 jam dengan kadar aspal $6 \%$, campuran AC-WC tahan terhadap pengaruh air, suhu dan cuaca.
\end{abstract}

Kata Kunci : Karakteristik, Marshall Immersion, pemadatan, suhu.

\section{PENDAHULUAN}

JaIan merupakan saIah satu prasarana transportasi yang berfungsi sebagai penghubung antara suatu tempat dengan tempat lainnya baik itu berupa kendaraan ringan maupun kendaraan berat (Rusbintardjo, 2013). Salah jenis lapisan permukaan sebagai bagian dari prasarana jalan adalah Asphalt Concrete (AC) atau aspal beton. Aspal beton sebagai lapisan permukaan terdiri atas Asphalt Concrete-Wearing Course (AC-WC), Asphalt Concrete-Binder Course (AC-BC) dan Asphalt Concrete-Base (AC-Base). Pada penelitian dikhususkan meneliti tentang Asphalt Concrete-Wearing Course (AC-WC). Salah satu faktor yang menentukan kekekalan konstruksi jalan adalah suhu pemadatan pada saat pelaksanaan pekerjaan. Hal ini akan mempengaruhi viskositas aspal yang digunakan. Menurut (Sukirman, 2013), untuk memperoleh infomasi tentang rentang temperatur perlu dilakukan pemeriksaan sifat kepekaan aspal tehadap temperatur. Pemeriksan sifat kepekaan aspal terhadap perubahan temperatur perlu dilakukan sehingga diperoleh informasi tentang rentang temperatur yang baik untuk pelaksanaan pekerjaan.

MateriaI yang digunakan pada campuran AC-WC berupa agregat kasar, agregat haIus, aspaI dan filler. Agregat kasar yaitu batuan yang tertahan di saringan $2,36 \mathrm{~mm}$, atau sama dengan saringan standar ASTM No. 8. Umumnya agregat kasar sangat penting dalam membentuk kinerja, karena stabilitas dari campuran diperoleh dari interlocking antar agregat. Agregat halus yaitu batuan yang lolos saringan No. 8 (2,36 mm) dan tertahan pada saringan No. 200 (0,075 mm). Fungsi utama agregat halus adalah memberikan stabilitas dan mengurangi deformasi permanen dari campuran melalui interlocking dan gesekan antar partikel. Aspal sebagai bahan pengikat campuran. AspaI bersifat viskoelastik dan tergantung pada waktu pemuatan. AspaI berperan sebagai pengikat agregat pada 
campuran beton aspal, sehingga penting untuk menjaga viskositas, titik lunak dan kelenturannya (Tandibua et al., 2020). Bahan pengisi atau filler adalah bahan yang lolos saringan nomor 200 (diameter $0,075 \mathrm{~mm}$ ). Filler berfungsi mengurangi rongga pada campuran beton aspaI, mengurangi permeabilitas dan meningkatkan kekuatan tarik. Filler dapat berupa semen tanah, bubuk batu, kapur, Semen Portland atau bahan Iainnya (Direkorat Jenderal Bina Marga, 2018). Pada penelitian ini menggunakan filler dari semen Portland.

Pengembangan teknologi dan inovasi di Era Revolusi 4.0 sangat mendukung penggunaan material lokal yang dapat dimanfaatkan sebagai bahan konstruksi jalan (Rachman, 2021). Selain itu, pada masa pandemi Covid-19 hubungan antar daerah sangat terbatas dengan adanya PSBB yang diterapkan disetiap daerah sehingga pengangkutan material sangat terbatas (Rachman, 2020a). Salah satu wilayah di Kabupaten Toraja Utara Provinsi Sulawesi Selatan yang memiliki sumber material yang dapat digunakan sebagai bahan untuk perkerasan jalan adalah Sungai Balusu di Kecamatan Awa' Karasik. Dimana pada penelitian ini akan menguji karakteristik sebagai bahan perkerasan jalan utamanya untuk campuran AC-WC.

PeneIitian sebelumnya yang meneliti tentang pengaruh suhu pemadatan Laston AC-WC antar lain, (Anindityo, 2011) meneliti pengaruh variasi temperatur pada proses pemadatan campuran aspai beton. (Raharjo et al., 2016) meneIiti tentang pengaruh suhu pemadatan campuran untuk perkerasan lapis antara (AC-BC).(Raya et al., 2015) meneliti tentang variasi temperatur pencampuran terhadap parameter Marshall pada campuran lapis aspal beton. (Rachman, 2020b) meneliti tentang efek perendaman dan kelembaban terhadap kinerja campuran bot rolled asphalt. (Bunga et al., 2019) meneliti tentang pengaruh variasi tumbukan terhadap indeks kekuatan sisa campuran AC-WC. Penelitian, yang meneliti tentang karakteristik material lokal sebagai bahan campuran AC-WC antara lain (Alpius, 2019) meneliti tentang karakteristi agregat batu gunung Desa Palipu Kecamatan Mengkendek Tana Toraja. (Rachman, 2020c) meneliti tentang karakteristik agregat Batu Gunung Bottomale Toraja Utara sebagai Campuran Laston. (Allo et al., 2019) meneliti tentang pemanfaatan agregat Sungai Wanggar Kabupaten Nabire sebagai bahan campuran AC-WC dan AC-BC. (Palimbunga et al., 2020) meneliti tentang penggunaan agregat Sungai Batu Tiakka' dalam Campuran AC-BC.

Tujuan penelitian untuk mengetahui pengaruh suhu pemadatan dengan beberapa variasi suhu pada campuran AC - WC serta menggunakan material agregat dari Sungai Balusu Kabupaten Toraja Utara. Variasi suhu pencampuran $90^{\circ} \mathrm{C}, 100^{\circ} \mathrm{C}, 110^{\circ} \mathrm{C}, 120^{\circ} \mathrm{C}, 130^{\circ} \mathrm{C}$, kadar aspal yang digunakan adalah $6 \%$. Penelitian ini didasarkan pada Spesifikasi Bina Marga 2018 Divisi 6.

\section{METODE}

\section{Lokasi pengambilan material}

Tempat pengambiIan material adalah Sungai Balusu, Kelurahan Balusu, Kecamatan Awak' Karasik, Kabupaten Toraja Utara. Akses menuju lokasi dapat dilewati truk pengangkut material. Bentuk material masih berupa batu yang berukuran diameter $\pm 20 \mathrm{~cm}$. Lokasi material ditunjukkan pada Gambar 1

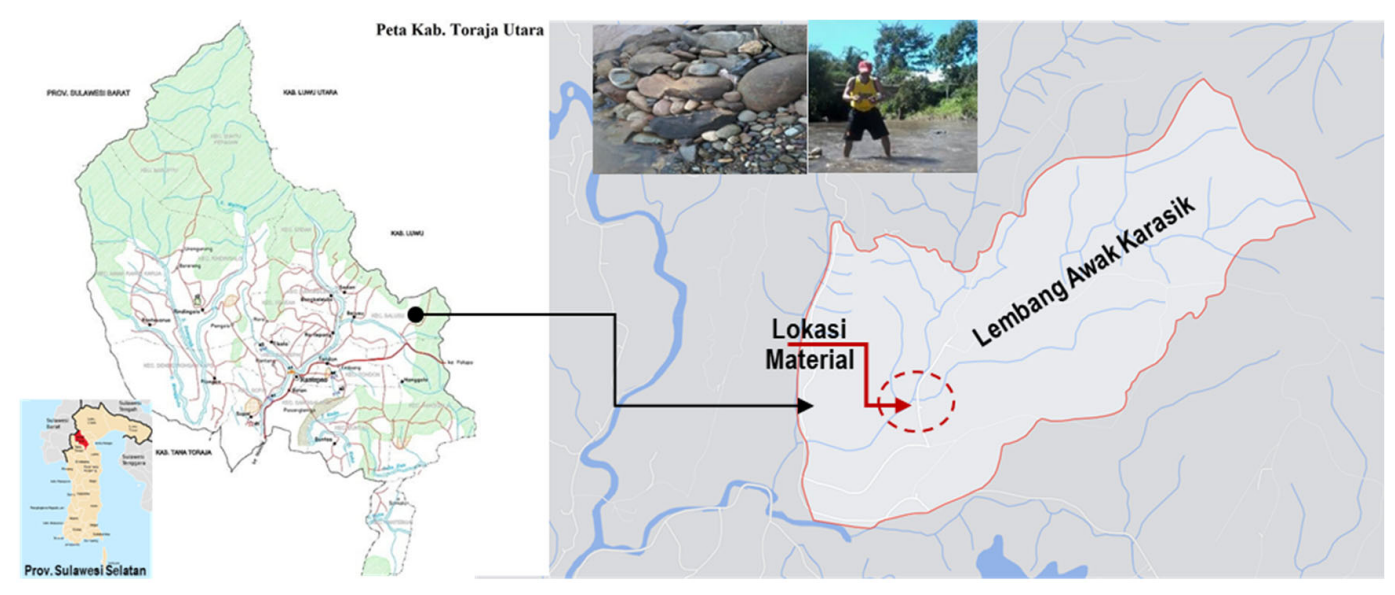

Gambar 1. Lokasi material 


\section{Pemeriksaan karakteristik agregat}

Pemeriksaan karakteristik agregat terdiri dari pengujian analisis saringan untuk agregat kasar, agregat halus dan filler mengacu pada (SNI-ASTM-C136, 2012). Pemeriksaan berat jenis curah (Bulk) dan penyerapan air dari agregat kasar merujuk pada (SNI 1969, 2016) sedangkan agregat haIus merujuk pada (SNI 1970, 2016). Pemeriksaan kadar lumpur dengan (SNI 03-4428, 1997). Uji keausan (Abration) mesin Los Angeles dengan (SNI 2417, 2008). Pengujian PartikeI Pipih dan Ionjong merujuk pada (ASTM D-4791-10, 2010). Uji kelekatan agregat dan aspal merujuk pada (SNI 2439, 2011). Pengujian agregat Iolos saringan $200 / 0.075 \mathrm{~mm}$ dengan (SNI ASTM C117, 2012).

\section{Pemeriksaan karakteristik aspal}

Metode yang digunakan daIam penelitian ini iaIah uji Penetrasi pada $25^{\circ} \mathrm{C}$ dengan (SNI 2456, 2011). Uji titik nyaIa ( $\left.{ }^{\circ} \mathrm{C}\right)$ dengan (SNI 2433, 2011). Uji titik lembek $\left({ }^{\circ} \mathrm{C}\right)$ dengan (SNI 2434, 2011). Pengujian Berat Jenis dengan (SNI 2441, 2011). Uji daktalitas dengan (SNI 2432, 2011). Uji berat yang hilang (\%) dengan (SNI 062441, 1991).

\section{Perencanaan campuran}

Komposisi rancangan campuran menggunakan gradasi ideal yaitu gradasi antara batas atas dan batas bawah seperti terlihat pada Tabel 1 .

\begin{tabular}{cccc}
\multicolumn{3}{l}{ Tabel 1. Perencanaan campuran } \\
\hline \multicolumn{2}{c}{ Dimensi saringan } & Spesifikasi & Rancangan \\
\hline lnch & mm & \% & $\%$ \\
\hline $3 / 4$ & 19 & 100 & 100 \\
$1 / 2$ & 12,5 & $90-100$ & 95 \\
$3 / 8$ & 9,5 & $77-90$ & 83,5 \\
4 & 4,75 & $53-69$ & 61 \\
8 & 2,36 & $33-53$ & 43 \\
16 & 1,18 & $21-40$ & 30,5 \\
30 & 0,6 & $14-30$ & 22 \\
50 & 0,3 & $9-22$ & 15,5 \\
100 & 0,15 & $6-15$ & 10,5 \\
200 & 0,075 & $4-9$ & 6,5 \\
\hline
\end{tabular}

\section{Komposisi campuran}

DaIam hal ini kadar aspaI dan variasi suhu yang gunakan berasaI dari penelitian sebeIumnya, yaitu peneIitian Ramsiadi Tandi Panga (2019) untuk Iapisan AC-WC adaIah kadar aspaI 6\% dan untuk variasi suhu mulai dari $90^{\circ} \mathrm{C}, 100^{\circ} \mathrm{C}, 110^{\circ} \mathrm{C}, 120^{\circ} \mathrm{C}, 130^{\circ} \mathrm{C}$. Komposisi campuran dapat dilihat pada table 2 dan jumlah benda uji dapat dilihat pada table 3

TabeI 2 Komposisi campuran

\begin{tabular}{llllll}
\hline \multirow{2}{*}{ MateriaI } & \multicolumn{5}{c}{ Suhu $\left(\mathbf{}{ }^{\circ} \mathbf{C}\right)$} \\
\cline { 2 - 6 } & $\mathbf{9 0}^{\circ} \mathbf{C}$ & $\mathbf{1 0 0}^{\circ} \mathbf{C}$ & $\mathbf{1 1 0}^{\circ} \mathbf{C}$ & $\mathbf{1 2 0}^{\circ} \mathbf{C}$ & $\mathbf{1 3 0}^{\circ} \mathbf{C}$ \\
\hline Agregat kasar (\%) & 37,20 & 37,20 & 37,20 & 37,20 & 37,20 \\
Agregat Halus (\%) & 50,90 & 50,90 & 50,90 & 50,90 & 50,90 \\
Filler (\%) & 5,90 & & & & \\
\hline
\end{tabular}

TabeI 3. JumIah benda uji

\begin{tabular}{llc}
\hline Kadar aspaI 6\% & Marshall konvensional & Marshall Immersion \\
\hline $90^{\circ} \mathrm{C}$ & 3 & \\
$100^{\circ} \mathrm{C}$ & 3 & 3 \\
$110^{\circ} \mathrm{C}$ & 3 & \\
$120^{\circ} \mathrm{C}$ & 3 & \\
$130^{\circ} \mathrm{C}$ & 3 & \\
\hline
\end{tabular}




\section{Pengujian Marshall konvensional}

Pengujian MarshalI konvensionaI dibagi atas tiga tahapan yaitu pengujian berat jenis, pengukuran stabilitas dan flow. Analisis Marshall konvensional dilakukan terhadap Stabilitas, Flow, VIM, VMA dan VFB.

\section{Penentuan suhu aspal optimum}

Dari pengujian Marshall konvensionaI, didapatkan suhu optimaI dengan menggunakan tabel desain metode MarshaII yang hasiInya berupa niIai stabilitas, niIai flow, kepadatan campuran, dan kepadatan agregat.

\section{Pengujian Marshall lmmersion}

Uji MarshaII Immersion mengacu pada (SNI 06-2489, 1991). Tujuan pengijian ini untuk mengetahui kekuatan campuran dari lamanya proses perendaman (suhu dan air), atau Stabilitas Marshall sisa.

\section{HASIL DAN PEMBAHASAN}

\section{Karakteristik materiaI}

\section{Agregat}

HasiI pengujian keausan agregat terhadap empat fraksi masing-masing fraksi A sebesar 15,72\%, fraksi B sebesar 17,18\%, 20,16\%, dan fraksi D sebesar 28,04\% sedangkan standar spesifikasi adalah maksimum 40\%. Hasil pengujian berat jenis dan penyerapan agregat kasar diperoleh niIai berat jenis buIk 2,73\%, berat jenis SSD $2,76 \%$, berat jenis semu 2,81\% dan penyerapan air 1,73\%. Standar spesifikasi untuk berat jenis SSD dan berat jenis semu adalah 1,05\% dan daya serap air maksimum 3\%. Hasil pengujian berat jenis dan absorpsi agregat halus adalah berat jenis bulk 2,54\%, berat jenis SSD 2,59\%, berat jenis semu 2,66\%, dan absorpsi air 1,73\%, Standar spesifikasi adalah yaitu berat jenis, berat bulk, berat jenis SSD, dan berat jenis semu minimal $2,5 \%$ sedangkan daya serap air minimaI 3\%. Hasil pengujian analisis saringan menunjukkan kombinasi agregat campuran berada antara batas atas dan batas bawah. Hasil pengujian dapat dilihat pada Gambar 2.

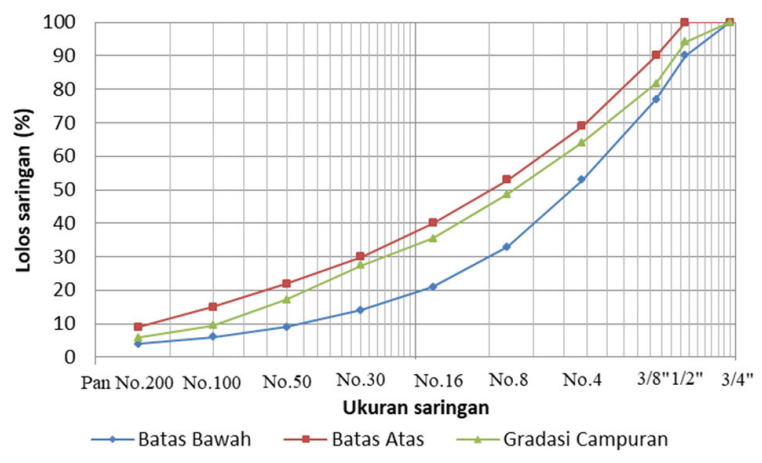

Gambar 2. HasiI pengujian analisa saringan

Hasil pengujian material lolos saringan No. 200 didapatkan nilai sebesar 1,0\% dimana standar spesifikasi adalah maksimaI 10\%. Hal ini menunjukkan material tersebut bersih dari lempung dan lanau. HasiI pengujian nilai setara pasir (SE) didapatkan nilai sebesar 96,26\%, persyaratan spesifikasi adalah minimal 60\% sedangkan kadar lumpur sebesar 3,74\% persyaratan maksimal 5\%. Dari hasil pengujian ini diketahui bahwa jumlah lumpur pada agregat cukup tinggi. HasiI pengujian partikel pipih diperoIeh nilai 7,97\%, 8,99\%, 4,81\% dan 0,00\% sedangkan partikel pipih yaitu $8,68 \%, 9,77 \%, 7,89 \%$, dan $0 \%$. Hasil pengujian ini memenuhi spesifikasi yaitu maksimal $10 \%$. HasiI pengujian keIekatan agregat terhadap AspaI didapatkan nilai sebesar 95,00\% dimana syarat spesifikasi minimum 95\%. Filler yang digunakan adalah Semen PortIand dan tidak lagi dilakukan pengujian.

\section{Aspal}

AspaI yang digunakan pada penelitian ini adaIah aspal minyak dengan penetrasi $60 / 70 \mathrm{~mm}$. HasiI niIai penetrasi adaIah $66,7 \mathrm{~mm}$ persyaratan sepesifikasi minimaI $60(0,1) \mathrm{mm}$ - maksimaI $70(0,1) \mathrm{mm}$. HasiI uji daktilitas didapatkan nilai rata-rata $150 \mathrm{~cm}$ persyaratan adalah $\geq 100 \mathrm{~cm}$. Dari hasil pengujian titik lembek aspal didapatkan nilai rata-rata $50,2^{\circ} \mathrm{C}$ dimana persyaratan adalah $\geq 48^{\circ} \mathrm{C}$. HasiI pengujian Titik NyaIa didapatkan nilai rata-rata 
Jurnal Matriks Teknik Sipil

DOI: https://dx.doi.org/10.20961/mateksi.v9i1.49248

ISSN: 2354-8630

E-ISSN: 2723-4223

Vol 9, No 1 (2021): Maret

$290^{\circ} \mathrm{C}$ sesangkan persyaratan adalah $\geq 2320^{\circ} \mathrm{C}$. Nilai rata-rata yang diperoIeh dari hasii uji daktilitas adalah 1,051 persyaratan $\geq 1,0$ gr. Hasil pengujian rata-rata penurunan berat aspaI sebesar $0,434 \%$ persyaratan adalah $\leq 0,8 \%$. HasiI uji penetrasi TFOT terhadap bobot aspaI diperoIeh niIai rata-rata $56.9 \%$ persyaratan adalah $\geq 54 \%$ dari penetrasi sebelum kehilangan berat

\section{Marshall konvensional}

Pada pengujian ini, menggunakan kadar aspal $6 \%$ dan variasi suhu adalah $90^{\circ} \mathrm{C}, 100^{\circ} \mathrm{C}, 110^{\circ} \mathrm{C}, 120^{\circ} \mathrm{C}, 130^{\circ} \mathrm{C}$. Dari hasiI perhitungan berat jenis dan massa jenis efektif didapatkan hasil seperti pada table 4.

Tabel 4. Berat jenis dan massa jenis efektif

\begin{tabular}{llllll}
\hline \multirow{2}{*}{ Nilai } & \multicolumn{5}{c}{ Kadar aspal $\mathbf{6 \%}$} \\
\cline { 2 - 6 } & $\mathbf{9 0}^{\circ} \mathbf{C}$ & $\mathbf{1 0 0}^{\circ} \mathbf{C}$ & $\mathbf{1 1 0}^{\circ} \mathbf{C}$ & $\mathbf{1 2 0}^{\circ} \mathbf{C}$ & $\mathbf{1 3 0}^{\circ} \mathbf{C}$ \\
\hline Berat Jenis & 2,81 & 2,81 & 2,81 & 2,81 & 2,81 \\
Massa Jenis Efektif & 2,81 & 2,87 & 2,87 & 2,87 & 2,87 \\
\hline
\end{tabular}

HasiI dari pengujian karakteristik Marshall konvensional yang meliputi VIM, stabilitas, VFB, flow dan VMA dapat dilihat pada Tabel 5.

Tabel 5. Hasil analisis Marshall konvensional

\begin{tabular}{llllll}
\hline $\begin{array}{l}\text { Kadar } \\
\text { Aspal } \\
\mathbf{6 \%}\end{array}$ & VlM(\%) & StabiIitas $(\mathbf{K g})$ & VFB (\%) & Flow $(\mathrm{mm})$ & VMA (\%) \\
\cline { 2 - 6 } & $\mathbf{3 - 5} \%$ & Min $800 \mathbf{~ K g}$ & Min 65\% & $\mathbf{2 - 4} \mathbf{~ m m}$ & Min 14\% \\
\hline $90^{\circ} \mathrm{C}$ & 4.732 & 1239.91 & 73.384 & 3.45 & 17.78 \\
$100^{\circ} \mathrm{C}$ & 4.332 & 1313.56 & 75.149 & 3.22 & 17.43 \\
$110^{\circ} \mathrm{C}$ & 3.839 & 1403.59 & 77.429 & 303 & 17.04 \\
$120^{\circ} \mathrm{C}$ & 3.404 & 1469.06 & 79.429 & 2.78 & 16.65 \\
$130^{\circ} \mathrm{C}$ & 3.026 & 1522.29 & 81.444 & 2.65 & 16.31 \\
\hline
\end{tabular}

\section{VlM ( Void In Mix)}

Rongga dalam campuran (VIM) adalah parameter yang menunjukkan volume rongga yang berisi udara dalam campuran dengan satuan persen volume (\%) (Sukirman, 2013). Hasil penelitian menunjukkan semakin bertambah suhu pemadatan, volume rongga dalam campuran semakin semakin berkurang, seperti dijelaskan pada Gambar 3. Berkurangnya volume rongga disebabkan karena semakin tinggi suhu, aspal semakin mencair sehingga aspal dapat mengisi rongga-rongga yang masih kosong. Persyaratan spesifikasi untuk VIM adalah 3\% sampai dengan 5\%, sedangkan hasil analisis nilai VIM yang terjadi adalah antara 3,026\% sampai dengan 4,732\%.

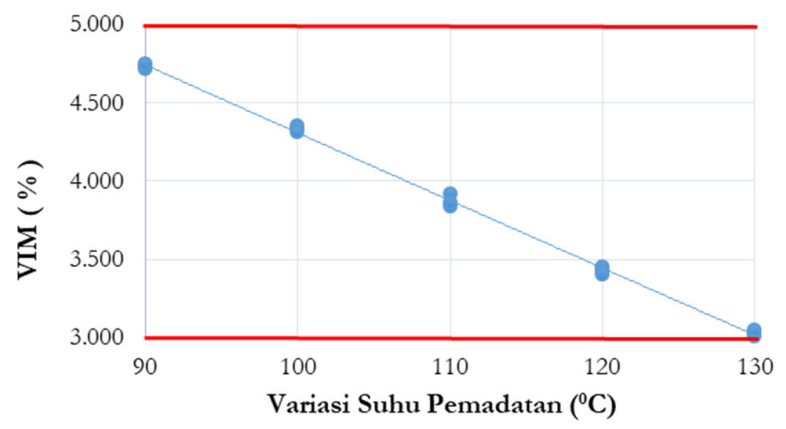

\section{Stabilitas}

Gambar 3. Hubungan antara VIM dengan variasi suhu

Stabilitas adalah kemampuan campuran aspal menerima beban sampai terjadi kelelehan plastis dengan satuan kilogram atau pound (Sukirman, 2013). Hasil penelitian stabilitas seperti pada Gambar 4. 
Jurnal Matriks Teknik Sipil

DOI: https://dx.doi.org/10.20961/mateksi.v9i1.49248

ISSN: 2354-8630

E-ISSN: 2723-4223

Vol 9, No 1 (2021): Maret

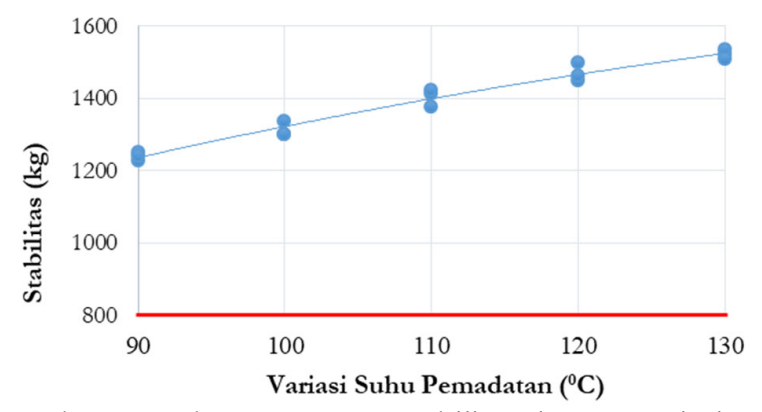

Gambar 4. Hubungan antara stabilitas dengan variasi suhu

Pada penelitian ini stabilitas cenderung meningkat sampai dengan suhu pemadatan $130^{\circ} \mathrm{C}$. Nilai stabilitas yang didapatkan adalah antara 1239,91 kg sampai dengan 1552,26 kg. Kenaikan stabilitas ini dikarenakan, pada suhu yang tinggi aspal akan mencair sehingga dapat menyelimuti agregat dengan sempurna dan ikatan antara aspal dan agregat semakin kuat.

\section{VFB (Void Filled with Bitumen)}

Rongga terisi aspal (VFB) adalah bagian volume rongga dalam agregat (VMA) yang terisi aspal efektif dalam satuan \% (Sukirman, 2013). Hasil pengujian VFB menunjukkan nilai antara 73,38\% sampai dengan $81,44 \%$ dimana pada pengujian ini, semakin bertambah suhu pemadatan nilai VFB juga semakin bertambah seperti terlihat pada Gambar 5. Hal ini dapat terjadi karena semakin tinggi suhu pemadatan, aspal akan bertambah cair dan aspal akan mengisi rongga secara keseluruhan. Persyaratan VFB sesuai dengan spesifikasi adalah minimum 65\%.

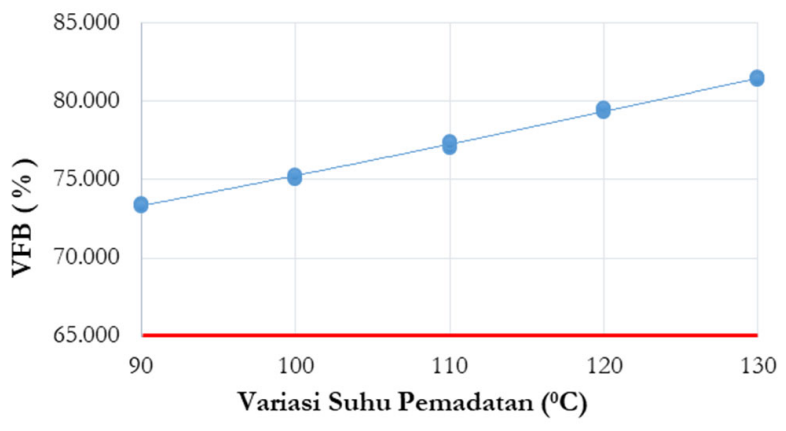

Gambar 5. Hubungan antara VFB dengan variasi suhu

\section{Flow}

Pelelehan (flow) adalah perubahan bentuk plastis dari campuran aspal yang terjadi akibat beban yang diterima sampai pada batas runtuh campuran tersebut yang dinyatakan dalam mm atau 0,01" (Sukirman, 2013). Hasil pengujian campuran aspal seperti pada Gambar 6 menunjukkan bahwa semakin bertambah suhu pemadatan nilai flow semakin berkurang. Nilai flow berkisar antara 2,65 mm sampai dengan 3,45 mm sedangkan persyaratan pada spesifikasi adalah antara $2 \mathrm{~mm}$ sampai dengan $5 \mathrm{~mm}$. FIow kecil akan mengakibatkan kelenturan campuran semakin menurun sehingga campuran semakin padat dan keras begitu sebaliknya

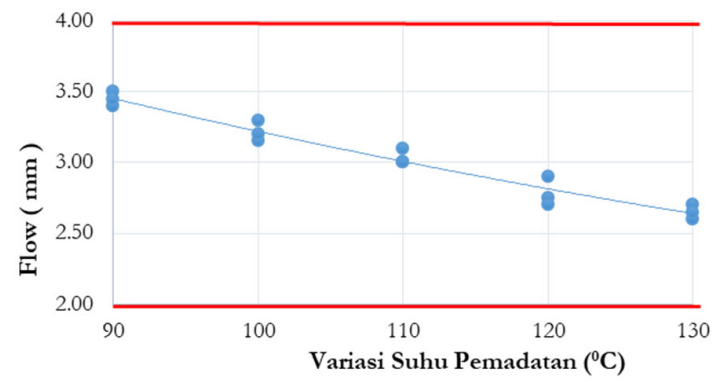

Gambar 6. Hubungan antara flow dengan variasi suhu 
Jurnal Matriks Teknik Sipil

DOI: https://dx.doi.org/10.20961/mateksi.v9i1.49248

ISSN: 2354-8630

E-ISSN: 2723-4223

Vol 9, No 1 (2021): Maret

\section{VMA (Void in Mineral Aggregate)}

Rongga didalam agregat (VMA) adalah volume rongga yang terdapat diantara butir-butir agregat dalam campuran aspal yang telah dipadatkan termasuk rongga udara dan rongga yang terisi aspal efektif dengan satuan \% (Sukirman, 2013). Hasil pengujian VMA dapat dilhat pada Gambar 7.

Dari Gambar 7, dapat diketahui bahwa semakin tinggi suhu pemadatan nilai rongga dalam agregat semakin berkurang. Pada suhu pemadatan $90^{\circ} \mathrm{C}$ nilai VMA sebesar $16,31 \%$, sampai pada suhu pemadatan $130^{\circ} \mathrm{C}$ nilai VMA menurun sampai dengan 17,78\%. Hal ini disebabkan rongga didalam agregat akan terisi oleh cairan aspal yang semakin panas, aspal semakin mencair. Persyaratan VMA sesuai dengan spesifikasi adalah minimu 14\%.

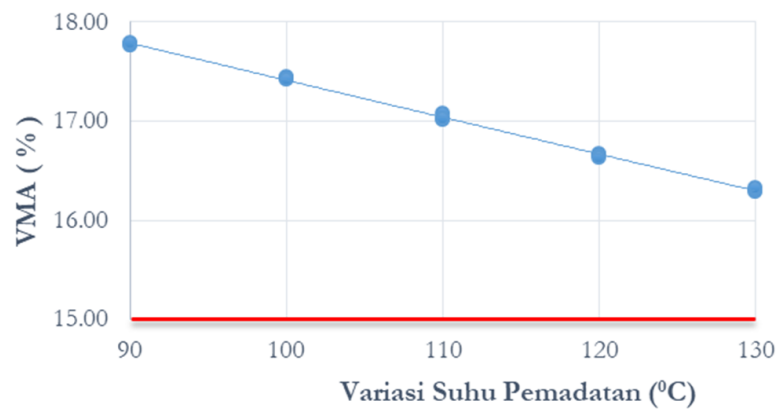

Gambar 7. Hubungan antara VMA dengan Variasi suhu

\section{Penentuan suhu optimum.}

Penentuan suhu pemadatan yang optimum untuk pembuatan benda uji dan pengujian Marshall Immersion. Dari hasiI anaIisis karakteristik campuran AC - WC pada TabeI 5, nilai VIM, stabilitas,VFB, flow dan VMA secara keseluruhan memenuhi persyaratan spesifikasi Bina Marga. Pada dasarnya keseluruhan variasi suhu pemadatan campuran dapat digunakan karena memenuhi persyaratan spesifikasi Bina Marga. Selanjutnya untuk pembuatan benda uji untuk pengujian Marshall Immersion digunakan suhu pemadatan $130^{\circ} \mathrm{C}$, penentuan kadar aspal optimum didasarkan pada nilai VIM yang terendah yaitu pada suhu $130^{\circ} \mathrm{C}$. Sesuai dengan hasil penelitian, pada suhu tersebut jumlah rongga dalam campuran mempunyai nilai terendah sehingga penyerapan air pada campuran sangat kecil.

\section{Stabilitas Marshall Sisa (SMS)}

Stabilitas Marshall sisa atau indeks kekuatan sisa adalah keawetan campuran aspal setelah terendam air. Pada penelitian ini, kadar aspal yang digunakan pada benda uji adalah $6 \%$ dengan suhu pemadatan $130^{\circ} \mathrm{C}$, kemudian direndam pada suhu $\pm 60^{\circ} \mathrm{C}$ selama 24 jam. Hasil pengujian dapat dilihat pada Tabel 6.

Tabel 6. Hasil pengujian Stabiltas Marshall sisa

\begin{tabular}{llll}
\hline \multirow{2}{*}{$\begin{array}{l}\text { Kadar } \\
\text { aspal (6\%) }\end{array}$} & \multicolumn{2}{c}{ Nilai Stabilitas } & $\begin{array}{l}\text { SMS } \\
\mathbf{n y y} \%\end{array}$ \\
\cline { 2 - 3 } $130^{\circ} \mathrm{C}$ & 1522.26 & 1497.71 & 98.39 \\
$130^{\circ} \mathrm{C}$ & 1534.54 & 1509.98 & 98.4 \\
$130^{\circ} \mathrm{C}$ & 1509.98 & 1485.43 & 98.37 \\
Rata-rata & 1522.26 & 1497.71 & 98.39 \\
\hline
\end{tabular}

Dari tabel 6, terlihat nilai stabilitas setelah perendaman selama 24 jam lebih kecil dari stabilitas konvensional. Masuknya air kedalam campuran setelah terendam air selama 24 jam akan mengurangi kekeuatan campuran. Hasil analisis stabilitas Marshall sisa (SMS) menunjukkan nilai rata-rata sebesar 98,39\%, nilai ini masih lebih besar dari persyaratan spesifikasi yaitu minimum $90 \%$. 
Jurnal Matriks Teknik Sipil

DOI: https://dx.doi.org/10.20961/mateksi.v9i1.49248

ISSN: $2354-8630$

E-ISSN: 2723-4223

Vol 9, No 1 (2021): Maret

\section{SIMPULAN}

Berdasarkan hasil penelitian dan pembahasan yang telah dijelaskan, maka dapat disimpulkan bahwa:

1. Batu dari Sungai Balusu dapat digunakan sebagai agregat pada campuran Asphalt Concrete-Wearing Course (ACWC).

2. Variasi suhu pemadatan $90^{\circ} \mathrm{C}, 100^{\circ} \mathrm{C}, 110^{\circ} \mathrm{C}, 120^{\circ} \mathrm{C}$ dan $130^{\circ} \mathrm{C}$ terhadap karakteristik campuran pada pengujian Marshall konvensional memenuhi persyaratan spesifikasi Bina Marga.

3. Stabilitas Marshall Sisa campuran dengan suhu pemadatan $130^{\circ} \mathrm{C}$ dan perendaman dengan durasi perendaman 24 jam dengan kadar aspal 6\%, campuran AC-WC tahan terhadap pengaruh air, suhu dan cuaca.

\section{REFERENSI}

Allo, F.L., Irianto, Elisabeth, Alpius, 2019., "Pemanfaatan Agregat Sungai Wanggar Kabupaten Nabire Sebagai Bahan Campuran AC-WC dan AC-BC", Paulus Civil Engineering Journal 1, pp. 28-36.

Alpius, 2019., "Campuran HRS-WC Menggunakan Agregat Batu Gunung Desa Palipu Kecamatan Mengkendek Tana Toraja", Konferensi Nasional Teknik. Sipil (KoNTekS) - 13, KoNTeks 13, pp. 431-441. Banda Aceh

Anindityo, A.W., 2011, "Analisa Pengaruh Variasi Temperatur pada proses Pemadatan Campuran Aspal Beton (Skripsi)", Program Studi Teknik Sipil Universitas Indonesia, Jakarta.

ASTM D-4791-10, 2010, "Method of Test for Percentage of Flat and Elongated Particles in Coarse Aggregate. State of California-Business", Transportation and Housing Agency.

Bunga, D.N., Rachman, R., Selintung, M., 2019, "Effect of Collision Variation towards the Index Retained Strength of Mixed Asphalt Concrete Wearing Course", International Journal of Scientific Engineering and Science 3, pp. 61-64. https://doi.org/10.5281/zenodo.3408003

Direkorat Jenderal Bina Marga, 2018, "Spesifikasi Umum Bina Marga 2018 untuk Pekerjaan Konstruksi Jalan dan Jembatan Divisi 6", Kementerian Pekerjaan Umum dan Perumahan Rakyat. Jakarta.

Palimbunga, G.P., Rachman, R., Alpius., 2020, "Penggunaan Agregat Sungai Batu Tiakka' dalam Campuran ACBC", Paulus Civil Engineering Journal, Vol. 2, pp. 112-118.

Rachman, R., 2021, " Bidang Transportasi, in: Pengembangan Teknologi Dan Inovasi Di Era Revolusi 4.0 (Konsep Dan Penerapan)", Tohar Media. Makassar, pp. 39-50.

Rachman, R., 2020a, "Transportasi, in: Dampak Pandemi Global Covid-19 Dalam Multi Perspektif", Tohar Media. Makassar, pp. 17-32.

Rachman, R., 2020b, "The Effect of Immersion and Humidification Toward Performance of Hot Rolled Asphalt Mixture", International Journal of Applied Engineering Research, Vol. 15, pp. 503-509.

Rachman, R., 2020c. "Pemanfaatan Batu Gunung Bottomale Toraja Utara sebagai Campuran Laston", Jumal Teknik Sipil dan Teknologi, Vol. 6, pp. 20-30.

Raharjo, B., Pratomo, P., Ali, H., 2016. "Pengaruh Suhu Pemadatan Campuran Untuk Perkerasan Lapis Antara (AC-BC)", JRSDD Vol. 4, pp. 43-50.

Raya, S.E., Pratomo, P., Herianto, D., 2015, "Variasi Temperatur Pencampuran Terhadap Parameter Marshall pada Campuran Lapis Aspal Beton.", JRSDD Vol. 3, pp. 455-468.

Rusbintardjo, G., 2013, "Aspal- Bahan Perkerasan Jalan", UNISSULA Press. Semarang.

Standar Nasional Indonesia, 1997, "(SNI) 03-4428: Pemeriksaan Kadar Lumpur Pasir", Badan Standardisasi Nasional.

Standar Nasional Indonesia, 1991, "(SNI) 06-2441: Metode Pengujian Berat Jenis Aspal Padat", Badan Standardisasi Nasional.

Standar Nasional Indonesia, 1991, "(SNI) 06-2489: Metode Pengujian Campuran Aspal dengan Alat Marshall", Badan Standardisasi Nasional.

Standar Nasional Indonesia, 2016, "(SNI) 1969: Cara Uji Berat Jenis dan Penyerapan Air Agregat Kasar", Badan Standardisasi Nasional.

Standar Nasional Indonesia, 2016, "(SNI) 1970: Metode Uji Berat Jenis dan Penyerapan Air Agregat Halus", Badan Standardisasi Nasional.

Standar Nasional Indonesia, 2008, "(SNI) 2417: Cara Uji Keausan Agregat dengan Mesin Abrasi Los Angeles", Badan Standardisasi Nasional.

Standar Nasional Indonesia, 2011, "(SNI) 2432: Cara uji daktilitas aspal", Badan Standardisasi Nasional.

Standar Nasional Indonesia, 2011, "(SNI) 2433: Cara Uji Titik Nyala dan Titik Bakar Aspal dengan Alat Cleveland Open Cup", Badan Standardisasi Nasional. 
Jurnal Matriks Teknik Sipil

DOI: https://dx.doi.org/10.20961/mateksi.v9i1.49248

ISSN: $2354-8630$

E-ISSN: 2723-4223

Vol 9, No 1 (2021): Maret

Standar Nasional Indoneisa, 2011, "(SNI) 2434: Cara Uji Titik Lembek Aspal Dengan Alat Cincin dan Bola (Ring And Ball)", Badan Standardisasi Nasional.

Standar Nasional Indonesia, 2011, "(SNI) 2439: Cara Uji Penyelimutan dan Pengelupasan pada Campuran Agregat-Aspal", Badan Standardisasi Nasional.

Standar Nasional Indonesia, 2011, "(SNI) 2441: Cara Uji Berat Jenis Aspal Keras", Badan Standardisasi Nasional.

Standar Nasional Indonesia, 2011, "(SNI) 2456: Cara Uji Penetrasi Aspal" Badan Standardisasi Nasional.

Standar Nasional Indonesia, 2012, "(SNI) ASTM-C117: Metode Uji Bahan Yang Lebih Halus Dari Saringan 75 Um (No. 200) Dalam Agregat Mineral Dengan Pencucian", Badan Standardisasi Nasional.

Standar Nasional Indonesia, 2012, "(SNI) ASTM-C136: Metode Uji Untuk Analisis Saringan Agregat Halus Dan Agregat Kasar", Badan Standardisasi Nasional.

Sukirman, S., 2013, "Beton Aspal Campuran Panas", Edisi Kedua. ed. Yayasan Obor Indonesia, Jakarta. 